\title{
PENGELOLAAN PERBATASAN DARAT INDONESIA-MALAYSIA DI KABUPATEN SAMBAS
}

\author{
Nur Syamsiah \\ Institut Agama Islam Sultan Muhammad Syafiuddin Sambas \\ nursyamsiahokey@gmail.com
}

\begin{abstract}
ABSTRAK
Tujuan dari penelitian ini untuk mencari formula dalam mengelola kawasan perbatasan darat Indonesia-Malaysia di Kabupaten Sambas. Permasalahan yang ada di kawasan perbatasan saat ini menyangkut kedaulatan bangsa dan negara serta mekanisme pengelolaan wilayah perbatasan. Selain itu terdapat permasalahan yang menyangkut kepentingan langsung masyarakat perbatasan. Terjadinya permasalahan tersebut sebagai akibat dari belum maksimal dalam pengelolaannya. Agar pengelolaan kawasan perbatasan darat Indonesia-Malaysia di kabupaten sambas bisa lebih baik, perlu beberapa hal yang harus dilakukan seperti membuat kebijakan yang mengatur tentang pengelolaan kawasan perbatasan, memaksimalkan peran pemerintah pusat, pemerintah daerah provinsi, pemerintah daerah kabupaten, masyarakat serta lembaga pengelola kawasan perbatasan.
\end{abstract}

Kata kunci: Pengelolaan, Perbatasan Darat

\begin{abstract}
ABTRACT
The purpose of this research is to find a formula to manage the landborder area between Indonesia andMalaysia in Sambas Regency.The present border area region issues involve national and state sovereignty as well as mechanism in magement of border areas. There is also an issue that concern the direct interests of border society. The occurrence of these issues as a result of not fully managed. To make land border area between Indonesia and Malaysia in Sambas district better, need some things that to do such as creating policies regulating to manage of border areas, maximize the role of the central government, provincial government,city government, society and border area management institutions.
\end{abstract}

Keywords:Management, Land Border 
Latar Belakang

Konvensi

Montevideo

menyebutkan wilayah negara menjadi

salah satu unsur berdiri satu

negara.(Assidiqi, 2006) Pasal 1 ayat (1)

Undang-Undang Nomor 43 Tahun

2008 Tentang Wilayah Negara

menyebutkan bahwa Wilayah negara

adalah salah satu unsur negara yang

merupakan satu kesatuan wilayah

daratan, perairan, pedalaman, perairan

kepulauan, dan laut teritorial beserta

dasar laut dan tanah dibawahnya, serta

ruang udara di atasnya, termasuk

seluruh sumber kekayaan yang

terkandung di dalamnya.

Wilayah negara memiliki

bagian terluar yang berbatasan

langsung dengan negara lain baik di

darat maupun di laut yaitu kawasan

perbatasan. Jahawir Thontowi

menyebutkan kawasan perbatasan

merupakan kawasan yang sering terjadi

permasalahan atau pelanggaran hukum.

(Thontowi, 2015) Mulai dari pengelolaan yang belum maksimal sampai terjadi pengklaiman wilayah oleh negara tetangga.

Pentingnya mengelola kawasan perbatasan sudah diamanatkan dalam UU nomor 43 tahun 2008 tentang Wilayah Negara, namun hingga saat ini masih terjadi permasalahan. Salah satu kawasan perbatasan yang terjadi permasalahan kawasan perbatasan darat Indonesia-Malaysia di kabupaten sambas.

\section{Metode Penelitian}

Penelitian ini termasuk penelitian empiris yaitu melakukan pengamatan langsung dilapangan dengan pendekatan kasus (case approach). Adapun metode yang di gunakan adalah deskriptif analisis dengan menggunakan pola induktif yaitu menganalisis untuk menarik suatu kesimpulan yang bersifat umum dari berbagai kasus yang bersifat khusus. Dalam hal ini lebih menekankan pada penalaran dengan menggambarkan hasil penelitian yang di peroleh di setiap dengan penjelasan logis dan sistematis dengan menguraikan, membahas, menafsirkan temuantemuan penelitian

\section{Hasil dan Pmbahasan}

\section{Konsep Perbatasan Darat}

Ahli geopolitik membagi istilah perbatasan menjadi boundaries dan frontier. (Hadiwijoyo, 2011) Perbatasan dalam istilah boundaries disebut juga bound or limit (mengikat atau membatasi) unit politik suatu negara. Boundaries digunakan jika suatu negara dipandang sebagai unit 
spasial yang berdaulat. Sementara istilah frontier menunujukan perbatasan letaknya front or hinterland (di depan atau di belakang) dari suatu negara. Bambang Istijono mengartikan Boundaries sebagai batas negara, sedangkan frontier diartikan sebagai kawasan perbatasan. (Istijono, 2012)

Suryo Sakti Hadiwijoyo mengklasifikasikan konsep kawasan perbatasan berdasarkan fungsional dan morfologi. Perbatasan berdasarkan fungsional

diklasifikasikan menjadi:

(Hadiwijoyo, 2011)

\section{a. Antesedent}

Boundaries (perbatasan duluan) yaitu perbatasan yang terbentuk karena negara-negara baru yang saling mendahului memasang atau menetapkan batas terluarnya.

b. Subsequent Boundaries yaitu perbatasan yang terbentuk setelah adanya cultural landscape dan dibuat setelah ada perundingan dan persetujuan bersama antar kedua negara.

c. Superimposed Boundaries yaitu perbatasan yang berdasar pada perundingan dan kesepakatan bersama antar kedua negara berdasarkan kepentingan politik.

d. Relic Boundaries yaitu perbatasan berupa garis yang kehilangan fungsi politisnya. Tipe ini biasa terjadi pada satu negara yang masuk kedalam wilayah negara lain.

Sedangkan kawasan perbatasan berdasarkan morfologi dibedakan menjadi: (Hadiwijoyo, 2011)

a. Artificial boundariesyaitu tandabatasyang dibuat oleh manusia, berupa tugu, kanal, terusan, patok dan sebagainya. Tandabatas model ini dibuat setelah ada kesepakatan dari kedua negara yang letaknya berhadapan atau berdampingan.

b. Natural boundaries yaitu tanda batas alami tanpa campur tangan manusia, seperti pegunungan, sungai, laut, hutan, gurun, serta antropologis. Tanda batas tipe ini digunakan sebelum adanya kesepakatan tertulis antar kedua negara.

$$
\text { Penetapan }
$$

wilayah perbatasan darat $d$ indonesia menggunakan prinsip Uti Possidetis 
Juris, yaitu penetapan wilayah negara berdasarkan warisan dari wilayah kekuasaan penjajah yang menguasai daerah tersebut. (Ludiro Madu, 2010) dalam hal ini, penentuan wilayah kedaulatan negara di darat berdasarkan wilayah jajahan belanda.

Prinsip uti possidetis juris digunakan dalam menetapkan batas wilayah darat indonesi yang berbatasan langsung dengan malaysia. Prinsip tersebut kemudian diperkuat dengan perjanjian anatar Indonesia-Malaysia dalam menetapkan garis batas negara di darat. Perjanjian yang sudah dibuat, antara lain konvensi Hindia Belanda dan Inggris tahun 1891, tahun 1915 dan tahun 1928. Panjang garis batas sekitar $2000 \mathrm{Km}$ yang di dasarkan pada batasan alam dengan mengikuti punggung gunung dan watershed (garis pemisah air). (Sombowadilr, 2008)

\section{Boundary Making Theory}

\section{Boundary making theory} merupakan teori pengelolaan kawasan perbatasan yang dicetuskan oleh Stephen B. Jones. Menurut teori ini terdapat empat tahap pengelolaan perbatasan yaitu Allocation,Delimination,
Demarcation, dan Administration. (Ludiro Madu, 2010) Keempat tahap tersebut saling terkait dan berkesinambungan sehingga menghasilkan satu rangkaian dalam pengambilan keputusan dalam pengelolaan kawasan perbatasan. (Bangun, 2014)

a. Allocation merupakan tahap awal berupa kejelasan wilayah perbatasan berdasarkan buktibukti historis danyuridis. (Tutik, 2017) Pada tahap ini pengumpulan data serta bukti hasil kesepakatan terkait garis batas kedua negara berupa perjanjian yang telah disepakati.

b. Delimination (penetapan batas), adalah penegasan garis batas perbatasan melalui serangkaian diplomasi berdasarkan buktibukti sejarah dan yuridis pada masa lalu. (Tutik, 2017) Tahap ini di lakukan identifikasi areaarea yang overlapping atau harus ditentukan batas-batasnya dengan Negara tetangga. Pada tahap ini penentuan titik koordinat dan pembuatan peta ilustrasi umum sebagai hasil dari kesepakatan. Kemudian kesepakatan tersebut di perkuat 
dengan pembuatan perjanjian internasional.

c. Demarcation (penegasan batas) adalah proses teknis dalam penentuan titik-titik patok perbatasan dilakukan dengan serangkaian kegiatan seperti survey dan pemetaan. (Tutik, 2017) Tahap ini dilakukan dengan memasang tanda batas (patok batas) di sepanjang garis batas yang telah disepakati dengan Negara tetangga. Tahap penegasan batas wilayah Negara sangat penting mengingat semakin pesatnya pertumbuhan dan perkembangan pembangunan yang memerlukan ruang baru bagi kebutuhan suatu negara. Jika tidak akan terancam hilang atau berubahnya batas wilayah suatu Negara atau saling klaim wilayah negara.

d. Administration (manajemen pembangunan) yaitu tahap pembangunan di berbagai sektor dan perencanaan yang terintegrasi dari berbagai bidang, seperti politik, sosial, pertahanan dan keamanan, ekonomi, budaya, lingkungan hidup, dan lainnya di kawasan perbatasan. (Ludiro Madu, 2010) Pada tahap ini juga di lakukan pengelolaan penduduk dan sumberdaya, pembagian kewenangan pemerintah pusat dan pemerintah daerah, serta pengelolaan CIQ (Costumers, Immigration And Quarantine) danlainnya. (Romi Nugroho dan Arditya Wicaksono, 2013)

Penerapan boundary making Stephen B. Jones dapat memudahkan pengelolaan kawasan perbatasan, karena bisa mengetahui kriteria dari kawasan perbatasan tersebut. Setiap kawasan perbatasan di wilayah negara Indonesia memiliki karakteristik yang berbeda-beda, mulai dari kondisi geografis, masyarakat serta kondisi negara tetangga yang berbatasan langsung dengan wilayah negara Indonesia. (Bangun, 2014)

3. Permasalahan

Kawasan Perbatasan Darat IndonesiaMalaysia di Kabupaten Sambas

Lesperssi dalam seminarnya berjudul good practices in border management and border security, lesson, learned in new democracies pada bulan Maret tahun 2007 memetakan permasalahn di kawasan perbatasan antara lain: (Ludiro 
Madu, 2010) Pertama, tidak lengkapnya landasan hukum nasional (Undang-undang perbatasan negara) dan internasional (kesepakatan bilateral maupun multilateral mengenai batas wilayah negara Indonesia. Kedua, tidak adanya pembagian wewenang yang jelas mengenai pengelolaan perbatasan negara. Jahawir Thontowi, kawasan perbatasan merupakan kawasan yang sering terjadi permasalahan atau pelanggaran hukum seperti tenaga kerja ilegal, klaim budaya/adat, pergeseran patok batas, nelayan ilegal. (Thontowi, 2015)

Berdasarkan data di
lapangan terdapat beberapa
permasalahan di kawasan perbatasan
Indonesia-Malaysia sebagaimana
dipaparkan oleh Suryo Sakti
Hadiwijoyo: (Hadiwijoyo, 2011)
Pertama, permasalahan yang
menyangkut kedaulatan bangsa dan negara serta mekanisme pengelolaan wilayah perbatasan, seperti pergeseran patok batas; Illegal Logging; TKI illagal, penyeludupan senjata api; potensi SDA belum di manfaatkan dengan baik; Kurangnya fasilitas sarana dan prasarana pendukung bagi pembangunan ekonomi regional dan nasional serta sarana dan prasarana sosial budaya untuk meningkatkan intelektual moral etika serta ketahanan budaya. Kedua, permasalahan yang menyangkut kepentingan langsung masyarakat perbatasan, seperti: rendahnya SDM, keterbatasan sarana dan prasarana ekonomi, pendidikan, kesehatan, keterbatasan aliran listrik dan jaringan internet, minimnya rasa nasionalisme masyarakat.

Terjadinya permasalahan di kawasan perbatasan indonesiamalaysia di kabupaten sambas disebabkan oleh faktor:

a. Penataan ruang dan pemanfaatan sumber daya alam belum jelas.

b. Kurang perhatian dari pemerintah, kebijakan pembangunan di kawasan perbatasan saat ini cenderung di fungsikan sebagai sabuk keamanan.

c. Belum maksilmal pengelolaanya karena secara geografis, kawasan perbatasan sangat luas, sehingga menyulitkan dalam pengelolaannya baik dari segi 
pelayanan, dana serta

pengelolaan

kawasan

kebutuhan aparatur.

perbatasan

mengingat

d. Kurang koordinasi dan

penanganannya bersifat lintas

kerjasama antar lembaga/sektor,

sehingga pengelolaannya tidak

maksimal.

e. Tingkat SDM yang masih rendah.

f. Keterbatasan infrastruktur seperti jalan, sarana kesehatan, sarana pendidikan, saluran komunikasi.

administrasi wilayah

pemerintahan dan lintas

sektoral. Dengan demikian memerlukan koordinasi dari institusi yang secara hierarki lebih tinggi.

k. Belum tersosialisasikannya regulasi mengenai pengelolaan kawasan perbatasan.

g. Lemahnya penegakan hukum, terjadi kasus pelanggaran hukum seperti penyeludupan barang/jasa (Sumuggling), Illegal Logging, Human Trafficing.

h. Belum optimal pengelolaam pemanfaatan sumber daya alam, seperti hutan, perkebunan.

i. Belum dibentuk badan pengelola perbatasan tingkat kabupaten, sebagaimana diamantkan dalam UndangUndang No 43 Tahun 2008 tentang wilayah negara untuk membentuk badan pengelola perbatasan tingkat nasional, daerah kprovinsi dan daerah kabupaten.

j. Belum memadainya kapasitas pemerintahan daerah dalam

1. Terbatasnya anggaran dana di pemerintahan daerah untuk membiayai pengelolaan kawasan perbatasan.

m. Masih ada tarik-menarik antara pemerintah pusat dan pemerintah daerah dalam mengelola kawasan perbatasan.

Kebijakan pengelolaan perbatasan di Kabupaten Sambas belum maksimal. Seringkali masyarakat umum bahkan stakeholders perbatasan masih sering mencampuradukan permasalahan yang ada. Hal tersebut berakibat pada solusi penyelesaiannya menjadi tidak fokus. Permasalahan koordinasi juga seringkali menjadi kendala. Ego sektoral dari para stakeholders berdampak pada tidak optimalnya 
pengelolaan perbatasan yang di lakukan. Selain itu, indikasi terhadap kurang taat terhadap aturan perundang-undangan yang berlaku yang di lakukan oleh pemerintah tersebut. Apalagi dengan berlakunya otonomi daerah, daerah hampir dapat memiliki dan melaksanakan seluruh kewenangan pemerintah pusat, kecuali urusan politik manca negara, pertahanan, keamanan, moneter dan fiskal, yustisi, agama. Dengan demikian, perlu cara dalam mengelola kawasan perbatasan.

\section{Pengelolaan Perbatasan Darat}

Pengelolaan merupakan aktivitas manajemen yang meliputi perencanaan, pengorganisasian dan pengawasan serta pengendalian. Pengelolaan kawasan perbatasan perlu memperhatikan aspek-aspek budaya masyarakat, pengaruh politik masyarakat kedua negara, kebijakan pemerintah negara serta kekuatan pasar dalam perdagangan. (Bangun, 2017)

Mengacu pada boundary making theory, di kabupaten sambas permasalahan Allocation (alokasi), Delimination (penetapan batas) serta Demarcation (penegasan batas ) telah selesai. Terbukti dengan adanya kesepakatan antara
Indonesia-Malaysia dalam menentukan garis batas darat kedua negara dengan di buat patok batas sepanjang garis batas wilayah kedua negara tersebut. Dengan demikian pengelolaan perbatasan di kabupaten sambas terfokus pada Administration (manajemen pembangunan). (Ludiro Madu, 2010)

Dalam mengelola kawasan perbatasan, perlu kebijakan pembangunan serta pengembangan kawasan perbatasan menjadi suatu konsepsi pembangunan yang jelas, komprehensif dan integratif. Untuk mencapainya perlu adanya pendataan dan perangkat analisis yang tepat. (Mufizar, 2012)

\section{a. Perundang-Undangan}

Terkait

pengelolaan perbatasan, telah diatur dalam peraturan. Peraturan perundangundangan menjadi landasan kerangka kebijakan yang dapat memayungi serta menyentuh seluruh aspek pengelolaan perbatasan,seperti:

1) UUD NRI tahun 1945 Pasal 25A.

2) Undang-Undang No. 43 tahun 2008 tentang wilayah negara. 
3) Peraturan Presiden Nomor 44 Tahun 2017 tentang Perubahan Atas Peraturan PresidenNomor 12 Tahun 2012 tentang Badan Nasional Pengelola Perbatasan.

4) Peraturan Menteri Dalam Negeri Nomor 140 Tahun 2017 tentang Badan Pengelola Perbatasan Daerah.

5) Peraturan Gubernur Kalimantan Barat No. 65 tahun 2008 Tentang Tugas Pokok, Fungsi Dan Tata Kerja Badan Pengelola Kawasan Perbatasan Dan KerjaSama (BPKPK) Provinsi Kalimantan Barat.

6) Peraturan Bupati Sambas

Nomor 31 tahun 2016 tentang Kedudukan, Susunan Organisasi, Tugas, Fungsi Dan Tata Kerja Sekretariat Daerah Kabupaten Sambas.

Dalam pengelolaan kawasan perbatasan darat, perlu kerjasama pemerintah pusat, pemerintah daerah, masyarakat serta lembaga yang berwenang mengelola kawasan perbatasan.

\section{b. Pemerintah Pusat}

Pasal 10 ayat (1) UndangUndang Nomor 43 Tahun 2008 Tentang Wilayah Negara memberikan kewenangan kepada pemerintah pusat dalam mengelola kawasa perbatasan . Kewenangan pemerintahan pusat antara lain: Menetapkan kebijakan pengelolaan dan pemanfaatan wilayah negara dan kawasan perbatasan; Mengadakan perundingan dengan negara lain mengenai penetapan batas wilayah negara sesuai dengan ketentuan peraturan perundangundangan dan hukum internasional; Membangun atau membuat tanda batas wilayah negara; Melakukan pendataan dan pemberian nama pulau dan kepulauan serta unsur geografis lainnya.

Kewenangan lain yang di miliki oleh pemerintah pusat dalam menjaga wilayah negara dan kawasan perbatasan antara lain Memberikan izin kepada penerbangan internasional untuk melintasi wilayah udara teritorial pada jalur yang telah di tentukan dalam peraturan perundangundangan; Memberikan izin lintas damai kepada kapal-kapal asing untuk melintasi laut teritorial dan perairan kepulauan pada jalur yang telah di tentukan dalam peraturan perundang-undangan; Melaksanakan pengawasan di zona tambahan yang di perlukan untuk mencegah 
pelanggaran dan menghukum pengawasan pelaksanaan pelanggar peraturan perundang- pembangunan kawasan perbatasan undangan di bidang bea cukai, yang di laksanakan pemerintah fiskal,imigrasi, atau saniter di dalam kabupaten/kota.

wilayah negara atau laut teritorial; Menetapkan wilayah udara yang di d. Pemerintah Daerah

\section{Kabupaten/Kota}

larang di lintasi oleh penerbangan internasional untuk pertahanan dan Kewenangan Pemerintah keamanan; Membuat dan memperbaharui peta wilayah negara dan menyampaikannya kepada dewan perwakilan rakyat sekurangkurangnya lima tahun sekali; Menjaga keutuhan, kedaulatan dan keamanan wilayah serta kawasan perbatasan.

\section{c. Pemerintah Daerah Provinsi}

Kewenangan pemerintah daerah provinsi dalam mengelola kawasan perbatasan terdapat dalam Pasal 11 ayat (1) Undang-Undang Nomor 43 Tahun 2008 Tentang Wilayah Negara, yaitu: Melaksanakan kebijakan pemerintah dan menetapkan kebijakan lainnya dalam rangka otonomi daerah dan tugas pembantuan; Melakukan koordinasi pembangunan di kawasan perbatasan; Melakukan pembangunan kawasan perbatasan antar pemerintah daerah dan/atau antara pemerintah daerah dengan pihak ketiga; Melakukan

daerah kabupaten kota dalam mengelola kawasan perbatasan terdapat dalam Pasal 12 ayat (1) Undang-Undang Nomor 43 Tahun 2008 Tentang Wilayah Negara, yaitu: Melaksanakan kebijakan pemerintah dan menetapkan kebijakan lainnya dalam rangka otonomi daerah dan tugas pembantuan; Menjaga dan memelihara tanda batas; Melakukan koordinasi dalam rangka pelaksanaan tugas pembangunan di kawasan perbatasan di wilayahnya; Melakukan pembangunan kawasan perbatasan antar pemerintah daerah dan/atau antara pemerintah daerah dengan pihak ketiga.

\section{e. Masyarakat}

Masyarakat juga berperan dalam pengelolaan kawasan perbatasan. Sebagaimana terdapat dalam pasal 19 ayat (1) UU wilayah negara masyarakat berperan mengembangkan pembangunan kawasan perbatasan; menjaga serta 
pempertahankan

kawasan

perbatasan. Dalam mengelola kawasan perbatasan, pemerintah pusat/daerah bisa mengikutsertakan masyarakat.

\section{f. Kelembagaan}

Dalam rangka percepatan penglolaan kawasan perbatasan dibentuk Badan Nasional Pengelola Nasional (BNPP) yang dipimpin oleh kepala badan yang bertanggungjawab kepada presiden. Pembentukan BNPP sebagai respon atas situasi serta tuntutan kebutuhan dalam upaya mempercepat penanganan ketertinggalan di kawasan perbatasan. Dengan demikian, BNPP diberi kekuasaan besar dalam melakukan pembangunan di kawasan perbatasan. (Saiman, 2017)

Adapun tugas dan fungsi

BNPP menurut Pasal 15 UU wilayah negara :menetapkan kebijakan program pembangunan perbatasan; menetapkan rencana kebutuhan anggaran; mengoordinasikan pelaksanaan, dan melaksanakan evaluasi dan pengawasan.

Selain membentuk BNPP di tingkat nasional, UU wilayah negara mengamantakan untuk membetuk badan pengelolaan kawasan perbatasan tingkat daerah provinsi dan kabupaten. Pembentukan badan pengelola perbatasan di tingkat daerah bertujuan untuk mempermudah koordinasi. Namun hingga saat ini belum terbentuk badan pengelolaan kawasan perbatasan di tingkat provinsi kalimantan Barat maupun kabupaten Sambas.

Saat ini penanganan perbatasan di provinsi Kalimantan Barat berada pada Badan Pengelola Kawasan Perbatasan dan Kerja Sama (BPKPK) Kalimantan Barat. BPKPK resmi di bentuk setelah adanya peraturan daerah provinsi Kalimantan Barat No. 10 tahun 2008 tentang susunan organisasi perangkat daerah provinsi Kalimantan Barat (tambahan lembaran daerah provinsi Kalimantan Barat tahun 2008, Nomor 8).

Tugas pokok dan fungsi Badan Pengelola Kawasan Perbatasan dan Kerja Sama (BPKPK) Kalimantan Barat antara lain: (Effendy, 2009) Penyusunan program bidang kerja sama; menyiapkan bahan dan perumusan kebijakan teknis di bidang kerja 
sama antar daerah; menyiapkan bahan dan perumusan kebijakan dan teknis di bidang kerja sama sub regional; pengawasan terhadap pelaksanaan tugas dan fungsi bidang kerja sama; pengoordinasian dan fasilitasi pelaksanaan tugas pokok dan fungsi di bidang kerja sama; pemberian dukungan penyelenggaraan pemerintah daerah di bidang kerja sama sesuai dengan peraturan perundang-undangan yang berlaku; pembinaan dan pengawasan di bidang kerja sama pada kabupaten/kota; pemberian saran dan pertimbangan kepada kepala badan berkenaan dengan tugas dan fungsi bidang kerja sama; pelaksanaan tugas lain di bidang di bidang kerja sama yang di serahkan oleh kepala badan.

Kewenangan BPKPK antara lain: (Effendy, 2009)melakukan kebijakan pembangunan di kawasan perbatasan secara fisik atau pembangunan prasarana yang di perlukan untuk menunjang pengelolaan kawasan perbatasan; melakukan monitoring, evaluasi, dan fasilitasi penataan kawasan dan pengembangan, pemberdayaan dan pengembangan masyarakat perbatasan dan kerja sama; melakukan kerja sama dengan bidang perbatasan dengan ketentuan perundang-undangan yang berlaku.

$$
\text { Sedangkan Penanganan }
$$

kawasan perbatasan kabupaten

Sambas berada pada bagian sekretariat daerah kabupaten Sambas khusus menangani kawasan perbatasan. Tugas dari sekretariat daerah kabupaten Sambas bagian kawasan perbatasan menurut pasal 56 peraturan Bupati Sambas Nomor 31 tahun 2016 tentang kedudukan, susunan organisasi, tugas, fungsi dan tata kerja sekretariat daerah kabupaten Sambas adalah: menyiapkan bahan perumusan kebijakan; koordinasi, evaluasi, fasilitasi dan pembinaan administrasi di bidang pengelolaan batas negara; pengelolaan potensi wilayah perbatasan dan pengelolaan infrastruktur kawasan perbatasan.

Menurut Pasal 57 Peraturan Bupati Sambas Nomor 31 Tahun 2016 tugas bidang perbatasan antara lain: Penyusunan dan penetapan rencana aksi pembangunan batas wilayah negara dan kawasan perbatasan di kabupaten; Pengoordinasian penetapan kebijakan dan pelaksanaan pembangunan, pengelolaan serta 
pemanfaatan betas wilayah negara dan kawasan perbatasan di kabupaten; Pengelolaan dan fasilitasi penegasan, pemeliharaan dan pengamanan batas wilayah negara di kabupaten; Inventarisasi potensi sumber daya dan rekomendasi penetapan zona pengembangan ekonomi, pertahanan, sosial budaya, lingkungan hidup dan zona lainnya kawasan perbatasan di kabupaten; Penyusunan program dan kebijakan pembangunan sarana dan prasarana perhubungan dan sarana lainnya di kawasan perbatasan kabupaten; Penyusunan anggaran pembangunan dan pengelolaan batas wilayah negara dan kawasan perbatasan sesuai dengan skala prioritas di kabupaten; Pelaksanaan, pengendalian dan pengawasan serta evaluasi dan pelaporan pelaksanaan pembangunan dan pengelolaan batas wilayah negara dan kawasan perbatasan di kabupaten; Pelaksanaan tugas kedinasan lainnya yang di berikan oleh pimpinan sesuai tugas dan fungsinya.

Guna menunjang kawasan perbatasan sebagai beranda terdepan dari suatu negara agar tidak tertinggal, perlu pembangunan kawasan berbatasan, seperti: (Mayona, 2011)

1. Memiliki pos lintas batas, di lengkapi dengan fasilitas CISQ (custom immigration security quarantine) di setiap daerah yang berbatasan langsung dengan negara lain.

2. Memiliki sarana dan prasarana yang memadai sesuai kebutuhan masyarakat sekitar.

3. Memiliki kualitas pendidikan yang tinggi.

4. Memiliki kualitas sumber daya manusia yang berkualitas, dari segi pendidikan, kesehatan, keterampilan masyarakat.

5. Memiliki tingkat kesejahteraan masyarakat yang setara dengan masyarakat di Negara tetangga.

\section{Kesimpulan}

Pengelolaan

kawasan perbatasan darat Indonesia-Malaysia di Kabupaen Sambas perlu untuk di reformulasikan. Untuk itu, perlu kerjasama antara pihak pengambil keputusan, akademisi dan praktisi perbatasan. Beberapa kebijakan yang ditawarkan dalam pengelolaan kawasan perbatasan darat Indonesia-Malaysia di Kabupaten Sambas, antara lain:Memperkuat tugas pemerintah pusat,daerah provinsi, daerah 
kabupaten, masyarakat dan lembaga pengelola kawasan perbatasan; Mempercepat dan memperluas ketersediaan infrastruktur; Memperkuat kemampuan jaringan kelembagaan perbatasan dengan saling berkoordinasi dan menghindari ego sektoral; Mempererat hubungan dengan negara tetangga melalui kerjasama yang saling menguntungkan; Meningkatkan kualitas kehidupan sosial budaya masyarakat di kawasan perbatasan.

\section{Daftar Pustaka}

Assidiqi, J. (2006). Pengantar Ilmu Hukum Tata Negara, jilid I. Jakarta: Sekretariat Jenderal dan kepaniteraan MK RI.

Bangun, B. H. (2014). Membangun Model Kerja Sama Pengelolaan Kawasan Perbatasan Negara di Kalimantan Barat-Serawak ( Suatu Studi Perbandingan. Jurnal MMH Jilid 43 No. 1.

Bangun, B. H. (2017). Konsepsi Dan Pengelolaan Wilayah Perbatasan Negara: Perspektif Hukum Internasional. TanjungPura Law Journal, Vol 1, Issue 1.

Effendy, C. (2009). Kewenangan Pemerintah Daerah dalam Pengelolaan Kawasan Perbatasan di Era Otonomi Daerah (Studi Kasus di Kalimantan Barat. Pontianak: TP.

Hadiwijoyo, S. S. (2011). Perbatasan Negara Dalam Dimensi Hukum Internasiona. Jogjakarta: Graha Ilmu.
Istijono, B. (2012). Pengelolaan Batas Wilayah Negara Dan Kawasan Perbatasan, Arah Kebijakan Menuju Kebijakan Yang Terarah. Puskastra Vol. 1 No. 1.

Ludiro Madu, D. (2010). Mengelola Perbatasan Indonesia Di Dunia Tanpa Batas:Isu, Permasalahan Dan Pilihan Kebijakan. Yogyakarta: Graha Ilmu.

Mayona, E. L. (2011). Penyusunan Arahan Strategi Dan Prioritas Pengembangan Perbatasan Antar Negara Di Provinsi Kalimantan Barat. Tata Kelola Vol. 13 No. 2.

Mufizar, d. (2012). Pembangunan Sosial Masyarakat Perbatasan Di Kecamatan Sajingan Besar Kabupaten Sambas Provinsi Kalimantan Barat. Jurnal PMIS UNTAN PSS.

Romi Nugroho dan Arditya Wicaksono, “. T.-J. (2013). Menata Sejengkal Tanah Di Ujung Batas Negara (Sinkronisasi Dan Koordinasi Lintas Kementrian Dan Lembaga Dalam Percepatan Pembangunan. Jejaring Administrasi Publik.

Saiman. (2017). Kepentingan Pemerintah Pusat Dalam Pembangunan Infrastruktur Perbatasan Kalimantan Indonesia-Malaysia Era Presiden Susilo Bambang Yudhoyono. Sospol, Vol. 3 No. 1 .

Sombowadilr, W. S. (2008). Daerah Perbatasan Keterbatasan Perbatasan. Jogjakarta: FUSPAD. 
Thontowi, J. (2015). Hukum Dan Diplomasi Lokal Sebagai Wujud Pemecahan Masalah Di Wilayah Perbatasan Kalimantan dan Malaysia. jurnal Yuridika Vol. 30 No. 3.
Tutik, T. T. (2017). Restorasi Hukum Tata Negara Indonesia Berdasarkan Undang-Undang Dasar Negara Republik Indonesia Tahun 1945. Depok: Prenadamedia Group. 